\section{Vulnerabilidade social e risco ambiental: uma abordagem metodológica para avaliação de injustiça ambiental}

\author{
Social vulnerability and environmental risk: \\ a methodological approach for evaluating \\ environmental injustice
}

\author{
${ }^{1}$ Instituto de Comunicação \\ e Informação Científica \\ e Tecnológica em Saúde, \\ Fundação Oswaldo Cruz, \\ Rio de Janeiro, Brasil. \\ 2 Programa de Pós-graduação \\ em Urbanismo, Universidade \\ Federal do Rio de Janeiro, \\ Rio de Janeiro, Brasil. \\ ${ }^{3}$ Escola Nacional de Saúde \\ Pública Sergio Arouca, \\ Fundação Oswaldo Cruz, \\ Rio de Janeiro, Brasil. \\ Correspondência \\ R. Cartier \\ Laboratório de Informação \\ em Saúde, Instituto de \\ Comunicação e Informação \\ Científica e Tecnológica em \\ Saúde, Fundação Oswaldo \\ Cruz. \\ Av. Brasil 4365, \\ Rio de Janeiro, $R J$ \\ 21045-900, Brasil. \\ ruycartier@gmail.com
}

\begin{abstract}
The aim of this article was to evaluate socioenvironmental vulnerability by selecting and analyzing socioeconomic, demographic, and infrastructural indicators around the Fazenda Botafogo Industrial Park in the city of Rio de Janeiro, Brazil, taking this work as a case study. The study aimed to determine whether there is a correlation between socially vulnerable groups and environmental risk, thus shaping a situation of environmental injustice. The study features a quantitative and spatial analysis based on the use of a geographic information system (GIS). The analyses show a strong correlation between social vulnerability and environmental risk, based on residents' proximity to factories in the target area. The indicators show that the populations with the worst socioeconomic conditions tend to live closest to the industrial sources of environmental risks. Inversely, the population groups with the best socioeconomic conditions tend to live the farthest from such sources.
\end{abstract}

Environment Risks; Social Vulnerability; Geographic Information Systems
Ruy Cartier 1

Christovam Barcellos 1

Cristiane Hübner 2

Marcelo Firpo Porto ${ }^{3}$

Nas últimas décadas, percebemos uma crescente preocupação de inúmeros pesquisadores com relação às injustiças ambientais, principalmente no que se refere à distribuição dos riscos ambientais frente às populações de baixa renda e grupos étnicos 1,2,3,4,5,6,7. Mais especificamente essas pesquisas avaliam se certos segmentos populacionais sofrem um dano desproporcional dos riscos ambientais. A recente atenção sobre a questão tem sua origem nos estudos da U.S. General Accounting Office 8 e da United Church of Christ's Commission for Racial Justice ${ }^{9}$. Esses estudos forneceram evidências de que havia uma discriminação baseada na raça ou etnia, mostrando que a distribuição espacial dos depósitos de resíduos químicos perigosos, bem como a localização de indústrias poluentes, não se fazia de modo aleatório: ao contrário, se sobrepunham e acompanhavam a distribuição territorial das etnias pobres nos Estados Unidos.

No Brasil, nos últimos anos, movimentos sociais e acadêmicos passaram a se dedicar às questões ligadas à justiça ambiental, o que resultou, em 2001, na criação da Rede Brasileira de Justiça Ambiental (RBJA) 10. A partir desse momento, surgiu a necessidade de ampliação do escopo do conceito de injustiça ambiental, de modo a ultrapassar meramente as questões raciais e de localização de riscos provenientes de origem química presentes no debate norte-americano. 
Desse modo, a RBJA passou a conceituar injustiça ambiental como: "o mecanismo pelo qual sociedades desiguais, do ponto de vista econômico e social, destinam a maior carga dos danos ambientais do desenvolvimento às populações de baixa renda, aos grupos sociais discriminados, aos povos étnicos tradicionais, aos bairros operários, às populações marginalizadas e vulneráveis" 11 (p. 14).

Em metrópoles brasileiras como São Paulo, Rio de Janeiro e Belo Horizonte (Minas Gerais) as parcelas mais pobres da população tendem a viver próximas a lixões, aterros sanitários, áreas inundáveis, plantas industriais, entre outros, constituindo um quadro de injustiça ambiental. Contudo, até o momento poucos estudos têm sido desenvolvidos visando a comprovar empiricamente essa distribuição. Os danos decorrentes das atividades industriais são a base para os estudos norte-americanos sobre injustiça ambiental. No entanto, as particularidades da estrutura sócio-espacial brasileira tornam necessária a ampliação do escopo das investigações, que devem incluir a falta de infra-estrutura e de serviços urbanos adequados 12 .

A vulnerabilidade socioambiental pode ser conceituada como uma coexistência ou sobreposição espacial entre grupos populacionais pobres, discriminados e com alta privação (vulnerabilidade social), que vivem ou circulam em áreas de risco ou de degradação ambiental (vulnerabilidade ambiental). Bullard 3, denomina essas regiões onde as populações pobres e discriminadas são forçadas a viver como "zonas de sacrifício". Normalmente, o conceito de vulnerabilidade social no campo ambiental ou dos desastres está associado a uma exposição diferenciada frente aos riscos, e designa a maior susceptibilidade de certos grupos populacionais preverem, enfrentarem ou sofrerem as conseqüências decorrentes de algum tipo particular de perigo 12,13.

A incorporação da temática da vulnerabilidade contribui para tornar visíveis as dificuldades adicionais que certas regiões, sociedades e populações têm em relação aos problemas ambientais 13,14, e ao mesmo tempo colabora para o esclarecimento de que certos problemas de ordem sócio-ambiental são decorrentes do atual modelo de desenvolvimento econômico, dos processos de deslocalização e desregulamentação, que intensificam as relações entre grupos vulneráveis e áreas de risco ambiental.

A escolha de moradia frente aos riscos ambientais geralmente está relacionada com a capacidade financeira dos grupos sociais. Se por um lado os grupos economicamente mais abastados podem abandonar áreas cujo ambiente oferece algum tipo de risco, por outro a cama- da populacional mais pobre não tem opção de saída destes espaços, fortalecendo o laço entre vulnerabilidade social e vulnerabilidade ambiental. Além da financeira, discriminações étnicas podem influenciar a concentração e segregação de determinados grupos populacionais em áreas de maior degradação e risco ambiental 2 .

O mesmo poder de atração que os terrenos de baixo valor exercem nas camadas populacionais mais pobres também influencia na alocação de investimentos industriais. As indústrias por necessitarem de terrenos extensos e baratos vão criar uma estreita relação com as classes economicamente fragilizadas. Ao mesmo tempo, a necessidade de mão-de-obra de baixo custo pelas indústrias, aliada à necessidade de emprego destas massas populacionais, cria um ambiente propício à perpetuação desta lógica.

Segundo Préteceille 15, as análises sobre tais processos devem identificar as diferentes realidades locais. Para o autor, as novas tecnologias são um aliado forte para a implementação de análises empíricas para evidenciar tais realidades. Entre as novas tecnologias adotadas destaca-se o uso de sistemas de informações geográficas (SIG). No entanto, Préteceille nos aponta para a dificuldade de acesso a dados estatísticos necessários aos diferentes tipos de estudo, o que gera um obstáculo na ampliação dessas tecnologias. A solução apontada para esse impasse se dá no recorte espacial a ser escolhido em uma análise, que deve coadunar com a escala correspondente à prática social da qual se quer privilegiar a análise.

Como enfatizaram Harner et al. 16, os pesquisadores há décadas vêm se empenhando na tentativa de mensuração das injustiças ambientais em outros países. Tais pesquisas têm utilizado diversas unidades de análises geográficas, tipos de testes estatísticos e indicadores. As variáveis comumente usadas para a mensuração de injustiças ambientais incluem, entre outras: a média da renda familiar 17; a população de não-brancos 18; o percentual da população de não-brancos 18,19; o percentual da população abaixo do nível de pobreza 19,20,21; a população de afro-americanos e hispânicos 21; a renda doméstica média e o percentual de negros 19. A EPA (Environmental Protection Agency, dos Estados Unidos), por exemplo, desenvolveu um índice em que as diferentes categorias para os graus de exposição (baseados na densidade populacional) foram multiplicados pelo grau de vulnerabilidade (com base na minoria e no ranking econômico) 23.

As unidades de análise utilizadas em pesquisas anteriores incluem os condados (municípios) 24,25, países 20 , zonas de postagem (CEP ou zip codes) ${ }^{9}$, setores censitários (census tracts) 
17,24,26 e grupos destes setores (census block groups) $19,21,24$

Nos Estados Unidos, existe um consenso acadêmico e governamental de que uma unidade espacial apropriada depende do objetivo da pesquisa e da escala na qual os dados são disponibilizados, uma vez que as questões de injustiça ambiental, nesse país, são questões locais focadas na menor unidade de área possível capaz de ser isolada para o estudo 27 .

De acordo com Zandberg e Chakraborty ${ }^{28}$, uma alternativa de aproximação para especificar o limite de uma região impactada consiste na construção de uma área de influência concêntrica (concentric ring buffer) para a fonte de poluição potencial.

Muitos estudos têm usado tais buffers ao redor da fonte a ser analisada para estimar áreas e populações em risco 19,21,29. Embora um buffer circular forneça uma delineação mais realista da área de exposição potencial de poluição, existem duas limitações associadas com esta aplicação na análise de exposição ambiental: (a) o raio do buffer circular é escolhido arbitrariamente (por exemplo, como 1.000 jardas, 1 milha, 1 quilômetro etc.); e (b) a dimensão das áreas de influência pode variar com a natureza e porte da fonte de risco.

No Brasil, os estudos que buscam utilizar abordagens metodológicas quantitativas ainda são escassos. Assim, este trabalho busca avaliar as condições e a configuração socioeconômica, demográfica e ambiental no entorno do Distrito Industrial (DI) Fazenda Botafogo, no Município do Rio de Janeiro. Procura-se articular o objeto teórico-conceitual de vulnerabilidade socioambiental e justiça ambiental com uma abordagem metodológica por meio do uso de um SIG que possa ser utilizado para a avaliação das possíveis disparidades sócio-econômicas em áreas de risco.

Adaptaremos a metodologia proposta, entre outros autores, por Mohai e Bryant 26, que elaboraram estudos para verificar a correlação entre raça e renda com risco ambiental. Para isso, os autores usaram uma abordagem pautada na criação de diferentes áreas de influência concêntricas (ring buffers) para analisar a composição étnica e o nível de renda no entorno de áreas de risco em Detroit e Chicago (Estados Unidos). A distância entre os habitantes e o distrito industrial é utilizada como proxy para risco ambiental.

Ressaltamos que a proposta é uma abordagem que possa ser usada para quantificar desigualdades sócio-ambientais, tendo consciência de que os processos que geram as vulnerabilidades e injustiças possuem natureza de ordem política, econômica e cultural.

\section{Área de estudo}

Oliveira 30, entende por DI uma área industrial planejada, estreitamente vinculada a um núcleo urbano e dotada de infra-estrutura física e de serviços de apoio necessários para a indução de um processo de desenvolvimento. Segundo o mesmo autor, os distritos industriais proliferaram em diferentes países, por iniciativa governamental, a partir da década de 1950, com o objetivo de estimular o desenvolvimento industrial em novas áreas. Os DIs, dentre eles o da Fazenda Botafogo, foram criados no final dos anos 60 pelo Estado do Rio de Janeiro, por meio da Companhia de Distritos Industriais (CODIN). A tendência mundial de incentivar o desenvolvimento industrial pela concentração de empresas dentro de áreas delimitadas no entorno das cidades foi o fator preponderante na escolha de tais projetos. A constituição de DIs apresenta como vantagens para as empresas os incentivos governamentais oferecidos e o rateio dos custos de infra-estrutura, tais como serviço bancário, de comunicação, energia e parqueamento ${ }^{31}$.

A localização do DI Fazenda Botafogo (Figura 1) seguiu uma estratégia que buscava aliar a proximidade de grandes redes viárias com áreas capazes de fornecer mão-de-obra para as indústrias que lá se instalavam. Um dos objetivos da CODIN ao implementar o distrito industrial nessa localidade era melhorar o perfil social da região 32. Se considerarmos que, segundo Abreu 33 , a área já era ocupada por uma população de baixa renda, podemos ter como resultado o que Gould 34 denomina "comunidades de desespero econômico". Segundo esse conceito, as comunidades pobres e operárias estão estruturalmente coagidas a aceitar qualquer iniciativa de desenvolvimento econômico que prometa um aumento no emprego local.

No ano de 2004, havia 33 indústrias instaladas na área do DI Fazenda Botafogo. Essas empresas atuam em diversos setores industriais, como: química, metalurgia, vidro, máquinas e equipamentos, plástico, material de limpeza etc. 32 . O DI Fazenda Botafogo localiza-se entre os bairros de Acari, Coelho Neto e Fazenda Botafogo, na zona norte da Cidade do Rio de Janeiro. Historicamente, tais bairros ocupavam a função de engenho de açúcar e a partir da década de 50, impulsionados com a construção da Avenida Brasil, passaram a pertencer ao subúrbio da cidade, abrigando moradias de baixa renda ${ }^{33}$. Atualmente, o bairro de Acari apresenta um dos maiores índices de pobreza do município 36 .

No entorno do DI referido neste trabalho já se verificou diversos conflitos ambientais envolvendo populações locais e algumas indústrias aloca- 

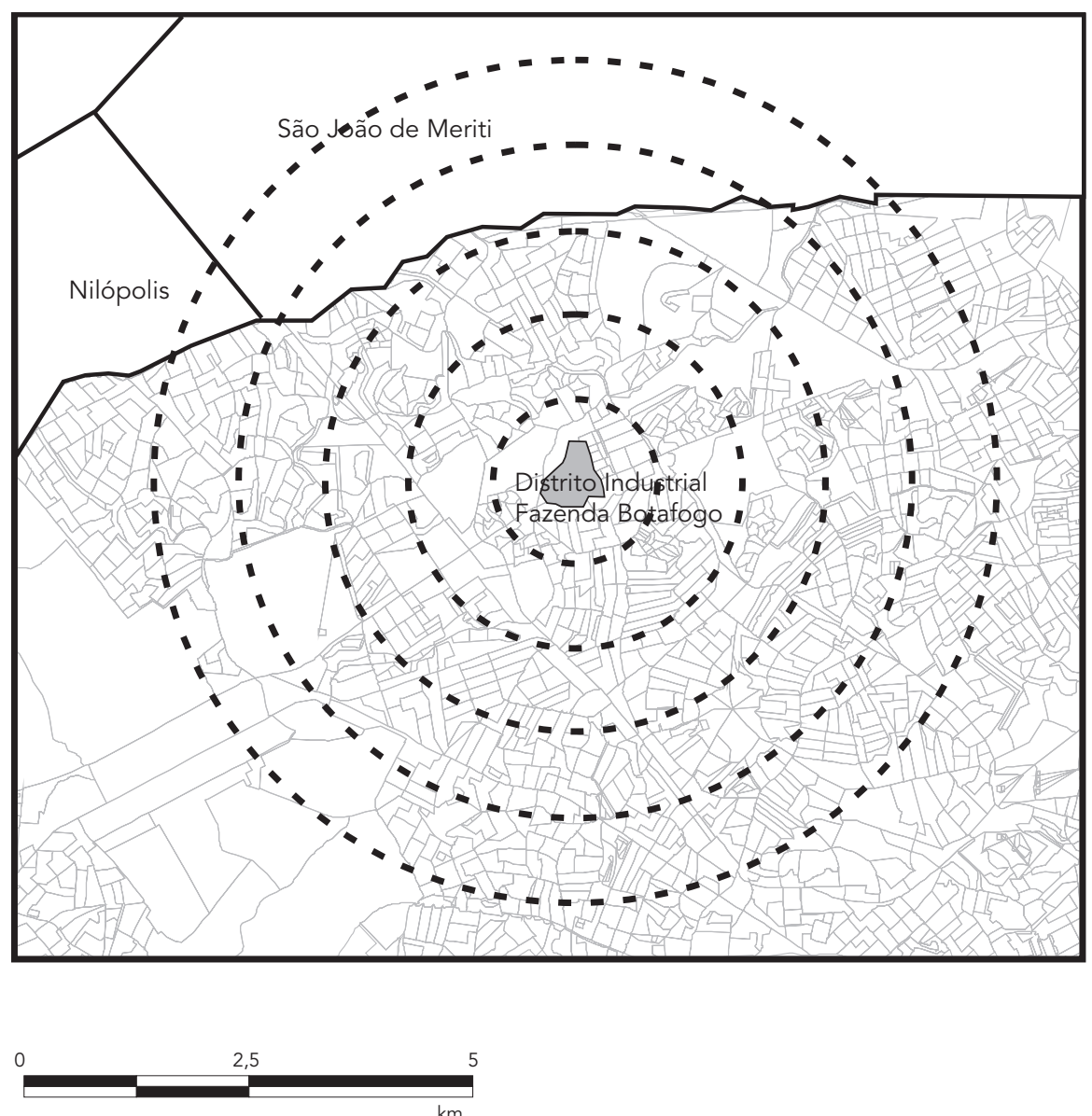

$\mathrm{km}$
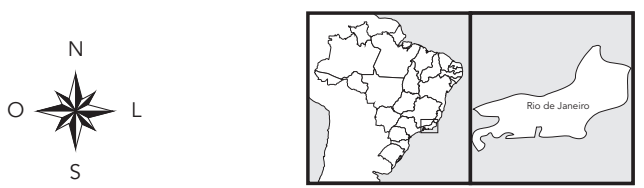

Legenda: Distrito Industrial Fazenda Botafogo em cinza e as cinco áreas de influência concêntricas (concetric ring buffers) em linhas tracejadas.

das no mesmo 36 . As denúncias revelavam danos referentes ao lançamento indevido de resíduos tóxicos em áreas abandonadas do seu entorno, bem como nos corpos hídricos da região. O rio Acari, que corta o do distrito industrial, apresenta altos níveis de contaminação, principalmente por esgotos domésticos e pelos dejetos industriais despejados das fábricas do DI 37 .
De acordo com a Lei $n^{\circ} .466^{38}$, de 21 de outubro de 1981, os distritos industriais têm a obrigatoriedade, por suas características, de estarem localizados em uma Zona Estritamente Industrial (ZEI). Segundo a lei: "I - Zonas de Uso Estritamente Industrial - ZEI: destinadas à localização de estabelecimentos industriais cujos resíduos sólidos, líquidos e gasosos, ruídos, vibrações, 
emanações e radiações que possam causar perigo à saúde, ao bem-estar e à segurança das populações mesmo depois da aplicação de métodos adequados de controle de tratamento de efluentes, nos termos da legislação vigente" (grifo nosso).

A caracterização do DI Fazenda Botafogo como uma ZEI revela as contradições e conflitos do processo de planejamento urbano no contexto metropolitano brasileiro: implantam-se fábricas perigosas em áreas já povoadas, e posteriormente intensifica-se, por meio de políticas públicas oficiais, o processo de ocupação para fins de moradia na região.

\section{Metodologia}

Como as injustiças ambientais são mediadas por processos de segregação espacial e concentração de populações pobres no entorno de fontes potenciais de risco, torna-se necessário adotar alguns instrumentos que permitam a análise de diferenciais sócio-econômicos no espaço urbano.

Este estudo foi realizado com a criação de cinco áreas concêntricas ao DI Fazenda Botafogo (Figura 1), distando $1 \mathrm{~km}$ entre si até o limite de $5 \mathrm{~km}$. A definição do tamanho e limite das áreas concêntricas utilizadas é controversa e ampla na literatura 39 . A escolha de raios de $1 \mathrm{~km}$ permitiu a criação de áreas com populações acima de 30 mil habitantes, o que garante maior estabilidade estatística aos indicadores calculados. Por outro lado, foi adotado o limite de $5 \mathrm{~km}$ em torno do DI, considerando que esta distância permite a identificação de um gradiente dos indicadores socioambientais e a verificação da correlação entre estes indicadores e a proximidade da área de estudo. Cabe ressaltar que os setores que não estão completamente contidos nas áreas de influência (buffers) foram distribuídos pelas áreas proporcionalmente à superfície do setor coberta por cada área. Esse critério estima a população contida em cada área supondo sua distribuição uniforme no setor. Foi avaliada a diferença entre estimativas de população segundo critérios (setores totalmente contidos nas áreas e setores parcialmente contidos nas áreas), chegando-se a um erro estimado de $2 \%$.

A escolha do local de estudo baseou-se na análise prévia dos cinco DIs do Município do Rio de Janeiro (Santa Cruz, Campo Grande, Paciência, Palmares e Fazenda Botafogo). O DI Fazenda Botafogo foi escolhido por estar instalado em área altamente urbanizada, o que não ocorre com os outros distritos, muitas vezes com características rurais. Os setores censitários nas áreas adjacentes ao DI Fazenda Botafogo possuem dimensões semelhantes, o que reduz a distorção dos dados obtidos neste estudo. Outro fator preponderante na escolha do DI foi o fato de o mesmo se encontrar distante dos demais distritos, não havendo assim interferência entre DI na análise realizada.

Para este trabalho foram consideradas as seguintes variáveis (obtidas nos dados censitários do ano de 2000 do Instituto Brasileiro de Geografia e Estatística - IBGE; http://www.ibge. gov.br): proporção de população residente em favelas (setores subnormais), percentual dos domicílios com esgotamento inadequado, percentual dos domicílios com coleta de lixo inadequada, percentual dos domicílios sem rede geral de abastecimento de água, renda média mensal dos responsáveis pelos domicílios, percentual dos responsáveis pelos domicílios particulares permanente com renda de 0 a 2 salários mínimos, percentual dos responsáveis pelos domicílios com renda mensal maior que 20 salários mínimos e percentual dos responsáveis pelos domicílios particulares permanentes com terceiro grau completo e nível de escolaridade (anos de estudo).

As análises espaciais e a gerência dos dados obtidos foram realizadas com o programa MapInfo (MapInfo Corp., New York, Estados Unidos), assim como os coeficientes de correlação de Pearson ( $r$ ) entre as variáveis estudadas e a variável discreta referente à distância $(\mathrm{km})$ dos buffers em relação ao DI foram obtidas usandose o programa estatístico SPSS (SPSS Inc., Chicago, Estados Unidos).

\section{Resultados}

De acordo com Tabela 1, os 5km circuncêntricos ao DI Fazenda Botafogo, contidos apenas no Município do Rio de Janeiro, possuem um total de 232.522 domicílios particulares. Como cada domicílio particular permanente possui um responsável, conseqüentemente os números de domicílios são os mesmos que os de responsáveis pelos domicílios próprios permanentes. A população total estimada foi de 785.455 habitantes.

Podemos verificar que, no que tange às infraestruturas urbanas, os dados revelam que existe efetivamente uma relação intrínseca entre a precariedade de serviços, a infra-estrutura e a proximidade ao DI.

O percentual de domicílios com esgotamento inadequado é mais elevado nos dois primeiros buffers ( $1 \mathrm{~km}$ e $2 \mathrm{~km})$, revelando, respectivamente, valores de $25,18 \%$ e $27,51 \%$, contra $20,72 \%$ para o terceiro buffer (3km), 20,42\% para o quarto $(4 \mathrm{~km})$ e $15,44 \%$ para o quinto $(5 \mathrm{~km})$.

Analisando os serviços de coleta de lixo inadequados, verifica-se que os maiores percentuais 
Tabela1

Valores dos indicadores utilizados referentes aos cinco buffers.

\begin{tabular}{|c|c|c|c|c|c|}
\hline \multirow[t]{2}{*}{ Indicadores } & \multicolumn{5}{|c|}{ Buffer (km) } \\
\hline & 1 & 2 & 3 & 4 & 5 \\
\hline População total & 37.970 & 124.694 & 194.825 & 202.141 & 225.825 \\
\hline Domicílios particulares permanentes & 11.178 & 35.618 & 57.838 & 60.057 & 67.831 \\
\hline Responsável pelo domicílio & 11.178 & 35.618 & 57.838 & 60.057 & 67.831 \\
\hline Domicílios com esgotamento inadequado & $2.814(25,18 \%)$ & $9.759(27,51 \%)$ & $11.982(20,72 \%)$ & $12.263(20,42 \%)$ & $10.774(15,44 \%)$ \\
\hline Domicílios com coleta de lixo inadequada & $391(3,5 \%)$ & $810(2,27 \%)$ & $1.293(2,24 \%)$ & $717(1,19 \%)$ & $214(0,31 \%)$ \\
\hline Domicílios sem banheiro & $150(1,34 \%)$ & $288(0,81 \%)$ & $400(0,69 \%)$ & $325(0,54 \%)$ & $358(0,38 \%)$ \\
\hline $\begin{array}{l}\text { Domicílios sem rede geral de abastecimento } \\
\text { de água }\end{array}$ & $97(0,87 \%)$ & $517(1,45 \%)$ & $949(1,64 \%)$ & $1.543(2,57 \%)$ & $398(0,59 \%)$ \\
\hline $\begin{array}{l}\text { Média de anos de estudo do responsável pelo } \\
\text { domicílio }\end{array}$ & 6,64 & 6,31 & 7,32 & 7,76 & 7,86 \\
\hline Responsável pelo domicílio analfabeto & $757(6,77 \%)$ & $2.752(7,73 \%)$ & $2.735(4,73 \%)$ & $2.262(3,77 \%)$ & $2.411(3,55 \%)$ \\
\hline $\begin{array}{l}\text { Responsável pelo domicílio com o terceiro grau } \\
\text { completo }\end{array}$ & $623(5,58 \%)$ & $1.871(5,25 \%)$ & $5.319(9,2 \%)$ & $7.531(12,54 \%)$ & $8.828(13,02 \%)$ \\
\hline $\begin{array}{l}\text { Renda média mensal do responsável pelo } \\
\text { domicílio (salários mínimos) }\end{array}$ & 3,61 & 3,26 & 4,39 & 5,3 & 5,53 \\
\hline $\begin{array}{l}\text { Responsável pelo domicílio com renda mensal } \\
\text { de } 0 \text { a } 2 \text { salários mínimos }\end{array}$ & $4.130(36,95 \%)$ & $15.097(42,39 \%)$ & $18.221(31,15 \%)$ & $16.367(27,25 \%)$ & $17.966(26,49 \%)$ \\
\hline $\begin{array}{l}\text { Responsável pelo domicílio com renda mensal } \\
\text { maior que } 20 \text { salários mínimos }\end{array}$ & $56(0,5 \%)$ & $173(0,49 \%)$ & $673(1,16 \%)$ & $1.258(2,09 \%)$ & $1.732(2,55 \%)$ \\
\hline População residente em favelas & $15.244(40,15 \%)$ & 52.742 (42,3\%) & $34.316(17,61 \%)$ & $20.648(10,21 \%)$ & $21.221(9,41 \%)$ \\
\hline
\end{tabular}

foram encontrados nos dois primeiros buffers, com valores respectivamente de $3,5 \%$ e $2,27 \%$. No terceiro buffer foi obtido o valor intermediário de $2,24 \%$. Os menores valores registrados, ou seja, melhores qualidades no serviço de coleta de lixo, foram encontrados nas áreas mais distantes do DI e referem-se ao quarto buffer, com 1,19\%, e ao quinto, com $0,31 \%$.

Outra variável fortemente ligada à precariedade de condições de vida e saneamento básico foi o percentual de domicílios sem banheiro. Novamente temos nos dois primeiros buffers os maiores valores, respectivamente, $1,34 \%$ e $0,81 \%$, contra os menores valores de $0,54 \%$ e $0,38 \%$ no penúltimo e último buffers, respectivamente. O terceiro buffer registrou o valor intermediário de $0,69 \%$.

O percentual de domicílios sem rede geral de abastecimento de água revelou uma tendência de crescimento quando aumentamos a distância relativa ao DI Fazenda Botafogo até ao quarto buffer. Tal observação, apesar dos valores relativamente baixos, nos indica que, excetuando o quinto buffer (menor valor observado: 0,59\%), as melhores condições de abastecimento de água podem ser verificadas no primeiro buffer, apenas 0,87\% dos domicílios, seguido do segundo com
$1,45 \%$, do terceiro com $1,64 \%$, e do quarto $b u$ ffer com 2,57\% dos domicílios sem rede geral de abastecimento de água.

O grau de escolaridade dos responsáveis pelos domicílios em torno do DI Fazenda Botafogo é analisado neste estudo, pois permite verificar se o alto grau de instrução está relacionado com a escolha do local de moradia. Quanto ao número médio de anos de estudo dos responsáveis pelo domicílio, observa-se que quanto maior a distância em relação ao DI maior é o número de anos de estudo do responsável. Os maiores valores obtidos encontram-se no quinto buffer com 7,86 anos de estudo, diminuindo para 7,76 anos quando observamos o quarto buffer. O valor intermediário de 7,32 anos de estudo foi encontrado no terceiro buffer. Os menores valores observados encontram-se no segundo buffer, 6,31 anos de estudo; seguido de 6,64 anos referentes ao primeiro buffer. Apesar de a variável referente aos anos de estudo já apontar dados relevantes entre uma redução do nível de escolaridade e a proximidade do DI, torna-se importante uma estratificação para observar o comportamento de duas camadas populacionais extremas.

A variação do percentual de responsáveis pelos domicílios com o terceiro grau completo indi- 
ca uma correlação entre o aumento da distância do DI. Os maiores percentuais de responsáveis com o terceiro grau completo encontram-se nas áreas mais afastadas. O maior percentual obtido está relacionado com o quinto buffer, no qual $13,02 \%$ têm o terceiro grau completo. O segundo maior percentual encontra-se no quarto buffer, com 12,54\%. Os dois primeiros buffers são caracterizados pelos menores valores percentuais, os quais são: $5,25 \%$ para o segundo, e 5,58\% para o primeiro. O valor intermediário ficou com o terceiro buffer, $9,2 \%$.

Quando observamos a distribuição de renda nos diferentes buffers, podemos observar que a renda média mensal dos responsáveis apresenta uma correlação positiva com o distanciamento do DI Fazenda Botafogo. O segundo buffer caracterizou-se por apresentar a menor renda média mensal (3,26 salários mínimos), e o quinto buffer apresentou a maior renda média mensal (5,33 salários mínimos), o que representou uma renda $65 \%$ maior que a do segundo buffer. O primeiro, terceiro e quarto buffers apresentaram, respectivamente, as rendas médias mensais de 3,61, 4,39 e 5,30 salários mínimos.

Analisando o percentual dos responsáveis pelos domicílios com renda de 0 a 2 salários mínimos podemos perceber que o maior percentual se encontra no segundo buffer, com $42,39 \%$. O segundo maior valor observado (36,95\%) está relacionado com o primeiro buffer. A partir do segundo buffer temos os seguintes valores decrescentes, respectivamente relacionados ao terceiro, quarto e quinto buffers: $31,5 \%, 27,25 \%$ e $26,49 \%$. De algum modo há uma tendência de uma maior concentração, em termos percentuais, de populações com renda de 0 a 2 salários mínimos nos buffers mais próximos do DI Fazenda Botafogo.

A variável relacionada com o grupo populacional de maior capacidade financeira, considerada aqui como o percentual de responsáveis pelos domicílios com rendimento maior que 20 salários mínimos mensais, apresentou correlação estatisticamente significativa com a distância em relação ao DI. O menor valor observado foi de $0,49 \%$, referente ao segundo buffer, seguido por um valor bastante próximo $(0,5 \%)$ correspondente ao primeiro. $\mathrm{O}$ valor intermediário de $1,16 \%$ caracteriza o terceiro buffer, bem como os valores de 2,09\% e 2,55\% referem-se, respectivamente, ao quarto e ao quinto buffers.

Torna-se igualmente interessante verificar se há ou não uma maior concentração de população residente em setores censitários denominados pelo IBGE de "subnormais" (favelas) no entorno do DI. Pode-se observar que os dois primeiros buffers apresentam um percentual da população residente em favelas bastante eleva- do, respectivamente, $40,15 \%$ e $42,3 \%$. O terceiro buffer apresentou-se como intermediário no que diz respeito ao percentual da população residente em favelas apresentando um valor de 17,61 , bastante inferior quando comparado aos dois primeiros buffers. O quarto buffer seguiu a tendência de queda revelando um percentual de $10,21 \%$. O quinto apresentou o menor valor percentual de populações residentes em favelas, $9,41 \%$.

Na Tabela 2 são verificados os coeficientes de correlação entre os indicadores utilizados e a distância dos buffers em relação ao DI.

De acordo com os resultados, os dois primeiros buffers, mais próximos do distrito, apresentaram as piores condições de saneamento básico, nível de renda e escolaridade, além dos maiores percentuais de população residente em favelas. Os dois buffers mais distantes da área analisada, referentes às distâncias de $4 \mathrm{~km}$ e $5 \mathrm{~km}$, apresentaram melhores condições de vida, baseadas nos indicadores aqui utilizados; o terceiro buffer (de $3 \mathrm{~km}$ ) se apresentou como área de características intermediárias entre as duas melhores áreas e as duas piores, segundo os dados analisados.

De igual modo, todos os indicadores apresentaram coeficiente de correlação estatisticamente significativo ( $\mathrm{p}<0,05$ ), com exceção do percentual dos domicílios com rede geral de abastecimento de água e do percentual dos responsáveis pelos domicílios com renda de 0 a 2 salários mínimos, que não apresentaram correlação significativa com a distância no nível de significância de 0,05.

\section{Discussão}

Com base na análise dos resultados deste trabalho podemos concluir que há uma forte correlação entre os indicadores selecionados e a proximidade do DI. Verificamos que, no que tange às infra-estruturas urbanas, os dados revelam que existe efetivamente uma relação entre a precariedade dos serviços, a infra-estrutura e a proximidade ao DI.

Os dados mostram que as populações com menores níveis de instrução tendem a estar localizadas nas áreas mais próximas ao risco. De modo inverso, temos as populações com os níveis de instrução mais elevados se alocando prioritariamente em áreas com menor risco ambiental.

Analisando a capacidade financeira dos responsáveis pelos domicílios observamos uma tendência similar ao que acontece com o nível de instrução escolar. A capacidade financeira dos responsáveis pelos domicílios esteve fortemente correlacionada com a distância em relação ao DI. 
Tabela 2

Coeficientes de correlação entre os indicadores utilizados e a distância dos buffers em relação ao Distrito Industrial.

\begin{tabular}{ll}
\hline Indicadores utilizados & Coeficiente de correlação (r) \\
\hline Domicílios com esgotamento inadequado (\%) & $-0,898$ \\
Domicílios com coleta de lixo inadequada (\%) & $-0,976$ \\
Domicílios sem banheiro (\%) & $-0,946$ \\
Domicílios sem rede geral de abastecimento de água (\%) & 0,038 \\
Média de anos de estudo do responsável pelo domicílio & 0,005 \\
Responsáveis pelo domicílio com o terceiro grau completo (\%) & 0,000 \\
Renda média mensal dos responsáveis pelos domicílios & 0,950 \\
Responsáveis pelos domicílios com renda de 0 a 2 salários mínimos (\%) & 0,929 \\
Responsáveis pelos domicílios com renda acima de 20 salários mínimos (\%) & $-0,847$ \\
População residente em favelas (\%) & 0,037 \\
\hline
\end{tabular}

Melhores condições de renda estiveram relacionadas às áreas mais afastadas.

Entendemos que os indicadores analisados neste estudo apresentam correlações entre si. No entanto, priorizamos aqui a apresentação das correlações observadas apenas com relação à distância da área de estudo, uma vez que isto possibilita verificar o processo de segregação espacial com maior especificidade.

O conjunto dos achados deste estudo pode revelar um padrão similar em outras realidades no Brasil. Tal padrão se refere a uma lógica de urbanização envolvendo a demarcação de distritos ou zonas industriais, que idealmente deveriam estar distantes de áreas de moradia. Diversos fatores nesses locais - infra-estrutura de transportes, possibilidades econômicas do mercado informal, existência de terrenos vazios para ocupação, dentre outros - atraem as populações mais pobres e sem condições de se candidatar a programas oficiais de moradia ou aluguéis formais. Nesse caso, a implantação de um distrito ou pólo industrial, ou mesmo uma fábrica ou instalação isolada de alto risco, ao mesmo tempo em que produz diversas situações de risco - como desastres, poluição atmosférica, contaminação hídrica e dos solos -, propicia novas formas irregulares de ocupação do solo por parte das populações mais pobres e excluídas da sociedade.

A metodologia utilizada, bem como os indicadores escolhidos e o local de estudo, nos fornecem evidências da possibilidade de mensuração das desigualdades sócio-espaciais frente aos riscos ambientais, sendo eficaz para avaliar desigualdades sócio-ambientais e evidenciar quadros de injustiças ambientais. A utilização de um SIG foi fundamental para a análise da vul- nerabilidade socioambiental da área de estudo, bem como tornou possível uma integração entre os dados provenientes dos setores censitários e a distância referente ao DI.

É importante ressaltar que as variáveis aqui inseridas normalmente não estão presentes nos debates norte-americanos, os quais prioritariamente dão enfoque às relações entre a distribuição dos riscos e danos provenientes de atividades antropogênicas poluentes e a espacialização de minorias étnicas e populações de baixa renda. A inserção de outras variáveis, além de raça e nível de renda, é capaz de trazer à tona elementos adicionais característicos das realidades locais do espaço urbano brasileiro, como falta de serviços, infra-estrutura urbana e nível de escolaridade. Tal inserção fortalece o movimento pela justiça ambiental, uma vez que amplia e territorializa as relações entre risco ambiental, vulnerabilidade, direitos e cidadania.

De todo modo, o debate teórico acerca da melhor metodologia para quantificar as disparidades socioambientais no território está longe de ser encerrado. Enquanto não existe uma solução metodológica definitiva, os esforços deste trabalho devem ser considerados como uma aproximação metodológica para estudos de desigualdade social e justiça ambiental. Sua principal contribuição reside no fato de ampliar a discussão metodológica, bem como inseri-la no cenário nacional, contribuindo assim para o fortalecimento do movimento pela justiça ambiental, fornecendo dados palpáveis que possam ser utilizados como suporte complementar para os argumentos teóricos dissertados na literatura referente às desigualdades ambientais, vulnerabilidades socioambientais, e (in)justiças ambientais. 


\section{Resumo}

O objetivo deste artigo é avaliar a vulnerabilidade sócio-ambiental por meio da seleção e análise de indicadores sócio-econômicos, demográficos e de infraestrutura no entorno do Distrito Industrial Fazenda Botafogo, no Município do Rio de Janeiro, Brasil, utilizado neste trabalho como estudo de caso. Buscou-se verificar nesse espaço se existe alguma correlação entre grupos socialmente vulneráveis e risco ambiental, conformando um quadro de injustiça ambiental. $O$ estudo caracteriza-se por ser uma análise quantitativa e espacial pautado na utilização de um Sistema de Informações Geográficas (SIG). As análises evidenciam uma forte correlação entre vulnerabilidade social e risco ambiental, tendo por referência a proximidade das indústrias na região escolhida. Os indicadores mostram que, na região analisada, as populações com as piores condições sócio-econômicas tendem a se localizar mais próximas às fontes industriais de riscos ambientais. De modo inverso, também foi verificado que os grupos populacionais com melhores condições sócio-econômicas tendem a se localizar mais distantes de tais espaços.

Riscos Ambientais; Vulnerabilidade Social, Sistemas de Informação Geográfica

\section{Referências}

1. Bryant B. Environmental justice: issues, policies and solutions. Washington DC: Island Press; 1995.

2. Bullard RD. Environmental racism and land use Land Use Forum: A Journal of International Law 1993; 18:6-11.

3. Bullard RD. Unequal protection: environmental justices and communities of color. San Francisco: Sierra Club Books; 1996.

4. Bullard RD. Enfrentando o racismo ambiental no século XXI. In: Acselrad H, Herculano S, Pádua JA, organizadores. Justiça ambiental e cidadania. Rio de Janeiro: Editora Relume-Dumará; 2004. p. 41-66.

5. Haughton G. Environmental justice and sustain able city. In: Satterhwaite D, editor. Sustainable cities. London: Earthscan; 1999. p. 62-79.

6. Marcondes MJA. Cidade e natureza. Proteção dos mananciais e exclusão social. São Paulo: Fundação de Amparo à Pesquisa do Estado de São Paulo/ Edusp/Studio Nobel; 1999.

7. Martinez-Alier J. Justiça ambiental (local e global). In: Cavalcanti C. organizador. Meio ambiente, desenvolvimento sustentável e políticas públicas. 2a Ed. São Paulo: Cortez Editora; 1999. p. 215-31.

\section{Colaboradores}

R. Cartier elaborou o estudo e redigiu o artigo. C. Barcellos organizou os dados, participou das discussões sobre os resultados e revisou o artigo. C. Hübner colaborou com a coleta e análise dos dados e revisou o artigo. M. F. Porto participou da análise e discussão dos resultados e revisou o artigo.
8. U.S. General Accounting Office. Siting of hazardous waste landfills and their correlations with racial and economic status of surrounding communities. Washington DC: U.S. General Accounting Office; 1983.

9. Commission for Racial Justices, United Church of Christ. Toxic wastes and race in the United States: a national report on the racial and socioeconomic characteristics of communities with hazardous wastes sites. New York: United Church of Christ; 1987.

10. Acselrad H, Herculano S, Pádua JA, organizadores. Justiça ambiental e cidadania. Rio de Janeiro: Editora Relume-Dumará; 2004.

11. Acselrad H, Herculano S, Pádua JA. A justiça ambiental e a dinâmica das lutas socioambientais no Brasil - uma introdução. In: Acselrad H, Herculano S, Pádua JA, organizadores. Justiça ambiental e cidadania. Rio de Janeiro: Editora Relume-Dumará; 2004. p. 14.

12. Porto MFS. Uma ecologia política dos riscos. Rio de Janeiro: Editora Fiocruz; 2007. 
13. Herculano S. Riscos e desigualdade social: a temática da Justiça Ambiental e sua construção no Brasil. In: I Encontro da ANPPAS - GT Teoria e Ambiente [CD-ROM]. São Paulo: Associação Nacional de Pós-graduação em Ambiente e Sociedade; 2002.

14. Freitas CM, Porto MFS. Discutindo o papel da ciência frente à justiça ambiental. In: II Encontro da ANPPAS - GT Justiça Ambiental, Conflito Social e Desigualdade [CD-ROM]. São Paulo: Associação Nacional de Pós-graduação em Ambiente e Sociedade; 2004.

15. Préteceille E. A construção social da segregação urbana: convergências e divergências. Espaço \& Debates 2004; 24:11-23.

16. Harner J, Warner K, Pierce J, Huber T. Urban environmental justice indices. Prof Geogr 2002; 54: 318-31.

17. Yandle T, Burton D. Reexamining environmental justice: a statistical analysis of historical hazardous waste landfill siting patterns in metropolitan Texas. Soc Sci Q 1996; 77:477-92.

18. Glickman TS. Measuring environmental equity with Geographical Information Systems. Renewable Resources Journal 1994; 12:17-21.

19. Chakraborty J, Armstrong MP. Exploring the use of buffer analysis for the identification of impacted areas in environmental equity assessment. Cartogr Geogr Inf Sci 1997; 24:145-57.

20. Cutter S, Holm D, Clark L. The role of scale in monitoring environmental justice. Risk Anal 1996; 16:517-26.

21. Sheppard E, Leitner H, McMaster RB, Hongguo T. GIS-based measures of environmental equity: Exploring their sensitivity and significance. J Expo Anal Environ Epidemiol 1999; 9:18-28.

22. Lester JP, Allen DW. Environmental justice in the U.S.: myths and realities. In: Western Political Science Association Annual Meeting. Seattle: Westview Press; 1999. p. 57-79.

23. Environmental Protect Agency. EPA risk screening guide. v. 1. The process. Washington DC: Federal Printing Office; 1989.

24. Cutter S, Clark L, Glickman TS, Golding D, Hersch R. GIS-based environmental equity analysis: a case study of TRI facilities in the Pittsburgh area. In: Wallace WA, Beroggi EG, editors. Computer supported risk management. Dordrecht: Kluwer Academic Publishers; 1995, p. 95-114.

25. Stockwell JR, Sorensen JW, Eckert Jr. JW, Carreras EM. The U.S. EPA geographic information system for mapping environmental releases of Toxic Chemical Release Inventory (TRI) chemicals. Risk Anal 1993; 13:155-64.
26. Mohai P, Bryant B. Environmental racism: reviewing evidence. In: Bryant B, Mohai P, editor. Race and the incidence of environmental hazards. Boulder: Westview Press; 1992. p. 163-246.

27. Kumar CM. GIS methods for screening potential environmental justice areas in New England [Masters Thesis]. Boston: Massachusetts Institute of Technology; 2002.

28. Zandberg PA, Chakraborty J. Improving environmental exposure analysis using cumulative distribution functions and individual geocoding. Int $\mathrm{J}$ Health Geogr 2006; 5:5-23.

29. Newmann CM, Forman DL, Rothlein JE. Hazard screening of chemical releases and environmental equity analysis of populations proximate to toxic release inventory facilities in Oregon. Environ Health Perspect 1998; 106:217-26.

30. Oliveira ACM. Distritos industriais: a experiência brasileira. Rio de Janeiro: Confederação Nacional da Indústria; 1976.

31. Dias R. Gestão ambiental: responsabilidade social e sustentabilidade. São Paulo: Editora Atlas; 2006.

32. Feichas SAQ, Abdalla JJA. Modelo "HACKEFORS" para obtenção de certificado ambiental ISO 14.000 em pequenas e médias empresas: uma discussão sobre sua aplicação em empresas brasileiras. Cadernos EBAPE.BR 2005; (3). http://www.ebape. fgv.br/cadernosebape/asp/dsp_texto_completo. asp?cd_pi=335684 (acessado em 13/Set/2009).

33. Abreu MA. Evolução urbana do Rio de Janeiro. Rio de Janeiro: IplanRio/Jorge Zahar Editor; 1987.

34. Gould KA. Classe social, justiça ambiental e conflito político. In: Acselrad H, Herculano S, Pádua JA, organizadores. Justiça ambiental e cidadania. Rio de Janeiro: Editora Relume-Dumará; 2004. p. 69-80.

35. Alvito M. As cores de Acari [Tese de Doutorado]. Rio de Janeiro: Fundação Getúlio Vargas; 2001.

36. Instituto de Pesquisa e Planejamento Urbano e Regional, Universidade Federal do Rio de Janeiro/Federação de Órgãos para Assistência Social e Educacional. Mapa dos conflitos ambientais do Rio de Janeiro [CD-ROM]. Rio de Janeiro: Instituto de Pesquisa e Planejamento Urbano e Regional, Universidade Federal do Rio de Janeiro/Federação de Órgãos para Assistência Social e Educacional; 2004.

37. Rego VS, Pfeiffer WC, Barcellos C, Rezende CE, Malm O, Souza CMM. Heavy metal transport in the Acari - São João de Meriti River System, Brazil. Environ Technol 1993; 14:167-74.

38. Lei n ${ }^{\circ}$. 466. Dispõe sobre o Zoneamento Industrial na Região Metropolitana do Rio de Janeiro. Diário Oficial do Estado do Rio de Janeiro 1981; 21 out.

39. Mennis J. Using geographic information systems to create and analyze statistical surfaces of population and risk for environmental justice analysis. Soc Sci Q 2002; 83:281-97.

Recebido em 22/Abr/2009

Versão final reapresentada em 29/Jul/2009

Aprovado em 03/Set/2009 